\title{
Er lavkarbodiett bedre enn diett med lite fett?
}

En ny studie viser at etter ett år har en diett med lavt innhold av karbohydrater større effekt på vektreduksjon og kardiovaskulære risikofaktorer enn en fettfattig diett.

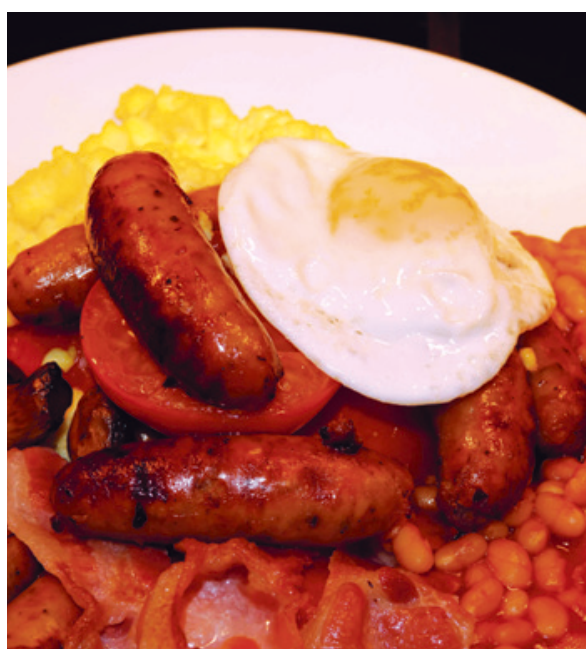

Illustrasjonsfoto: R. Stonehouse/Camera Press/NTB scanpix
Effekten av karbohydratfattig kost på risiko for kardiovaskulær sykdom er uavklart. I en ny studie har amerikanske forskere sammenliknet effekten av lavkarbohydratdiett med fettfattig diett på vektreduksjon og kardiovaskulære risikofaktorer (1).

Personer med betydelig overvekt (BMI $30-45 \mathrm{~kg} / \mathrm{m}^{2}$ ) ble randomisert til to ulike kostråd som skulle følges i 12 måneder. Halvparten fikk råd om å spise $<40 \mathrm{~g}$ karbohydrat per dag og fikk utdelt en lavkarbohydratdrikk eller -bar for hver dag, mens den andre halvparten skulle spise $<30$ energiprosent fett og fikk utdelt en fettfattig drikk eller bar. Alle fikk råd om å bruke umettet fett og å spise mer kostfiber.

Etter 12 måneder hadde lavkarbohydratgruppen $(\mathrm{n}=59)$ redusert kroppsvekten med $3,5 \mathrm{~kg}$ mer enn lavfettgruppen $(\mathrm{n}=60)$. Totalkolesterol, LDL-kolesterol, fastende glukose, insulin, systolisk og diastolisk blodtrykk var uendret $\mathrm{i}$ begge grupper, mens triglyseridene falt med $0,23 \mathrm{mmol} / \mathrm{l}$ i lavkarbohydratgruppen, mot $0,07 \mathrm{mmol} / \mathrm{i}$ lavfettgruppen. HDLkolesterol økte med 0,24 mmol/1 i lavkarbohydratgruppen, mot $0,06 \mathrm{mmol} / \mathrm{l} \mathrm{i}$ lavfettgruppen.
- Det finnes flere studier ved alvorlig overvekt som har vist størst effekt av lavkarbohydratkosthold etter 12 måneder, sier professor Kjetil Retterstøl ved Avdeling for ernæringsvitenskap, Universitetet i Oslo. Men i noen få studier som har vart i to år, ser man alltid at vektforskjellene konvergerer. Den aktuelle studien er ikke stor nok og varer ikke lenge nok til å gi informasjon om harde endepunkter. Studien er randomisert og prospektiv, men naturligvis ikke blindet og mangler beviskraften som ligger i et dobbeltblindet design. De nordiske kostrådene fra 2013 anbefaler at vi spiser mindre mettet fett, slik også Verdens helseorganisasjon anbefaler, sier Retterstøl.

Trine B. Haugen

Tidsskriftet

Litteratur

1. Bazzano LA, Hu T, Reynolds K et al. Effects of lowcarbohydrate and low-fat diets: a randomized trial. Ann Intern Med 2014; 161: 309-18.

\section{Både kvalitet og nærhet}

\author{
Mange pasienter foretrekker akuttinnleggelse på lokal sykestue fremfor \\ på et sykehus som ligger lenger unna.
}

Hallingdal sjukestugu har med sin døgnbemanning i flere år tatt imot akuttinnleggelser av pasienter fra Hallingdal med behov for observasjon eller enklere medisinsk behandling. I en studie vi nylig har publisert i tidsskriftet Social Science \& Medicine, ble 60 pasienter som allmennlegen ønsket å innlegge akutt ved Hallingdal sjukestugu, randomisert til innleggelse i sykestuen eller i Ringerike sykehus (1). Ved utskrivning besvarte pasientene et spørreskjema om pasientopplevd kvalitet. På flere områder var det signifikant bedre resultater for gruppen som hadde vært innlagt ved Hallingdal sjukestugu, til tross for at Ringerike sykehus har skåret høyt i landsomfattende undersøkelser der man har brukt tilsvarende spørreskjema (PasOpp).

For å utdype disse resultatene brukte vi en kvalitativ tilnærming med pasientintervjuer og fokusgruppeintervju med viktige aktører ved og rundt Hallingdal sjukestugu. Pasientene vektla mindre forhold, roligere atmosfære, kontinuitet $\mathrm{i}$ behandlingen og helhetlig pasienttilnærming. De la liten vekt på innspart reiseavstand til Ringerike sykehus $(170 \mathrm{~km})$ og følte seg trygge på at de ville bli videresendt til sykehus om nødvendig. Fokusgruppen viste til stor tillit til Hallingdal sjukestugu i befolkningen og det nære samarbeidet med sykehus og fastleger.

Vi mener denne studien har relevans for samhandlingsreformen i helsevesenet og mål om øyeblikkelig hjelp-senger utenfor sykehus. Pasientenes prioriteringer støtter oppbyggingen av et mer differensiert akuttilbud uavhengig av geografisk avstand.

\section{Øystein Lappegard}

oystein.lappegard@vestreviken.no

Hallingdal sjukestugu

\section{Litteratur}

1. Lappegard O, Hjortdahl P. Perceived quality of an alternative to acute hospitalization: An analytical study at a community hospital in Hallingdal, Norway. Soc Sci Med 2014; 119C: 27-35

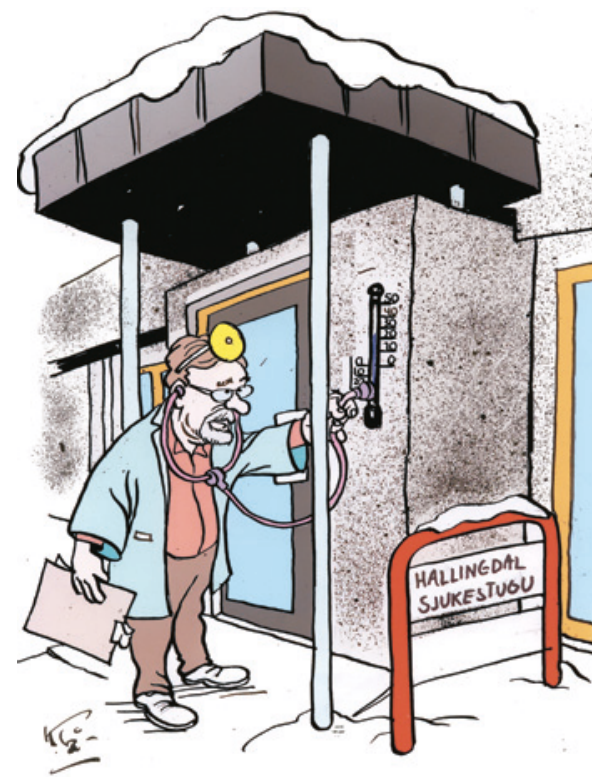

Illustrasjon: Ola B. Klåpbakken/Hallingdølen 